\title{
EVALUASI DIMENSI BAK PENGENDAP LUMPUR SISA PRODUKSI IPAM KARANG JOANG 100 LPD KOTA BALIKPAPAN
}

\author{
Erwin Gustianta ${ }^{1}$, Rachmasari Pramita Wardhani ${ }^{2}$, Rissetridharma Simanjuntak ${ }^{3}$ \\ 1,2,3 Jurusan Teknik Mesin, Fakultas Teknik, Universitas Tridharma, Balikpapan \\ e-mail: r.winsirfa@gmail.com,rachmadosen@gmail.com,rissetri@gmail.com
}

\begin{abstract}
Abstrak
Pengolahan limbah sisa produksi di instalasi pengolahan air minum Karang Joang Kapasitas 100 Lpd (IPAM Karang Joang) merupakan upaya PDAM Kota Balikpapan untuk menjaga lingkungan dari bahan pencemar yang dihasilkan IPAM Karang Joang dari proses produksi. Pengolahan air limbah yang dilakukan PDAM Kota Balikpapan di IPAM Karang Joang bermanfaat untuk menambah volume air baku melalui proses pemanfaatan kembali air hasil pengolahan limbah produksi. Namun demikian diperlukan perhitungan yang tepat mengingat keterbatasan lahan yang ada.
\end{abstract}

Kata kunci-limbah , Instalasi , Pengolahan, karang Joang

\begin{abstract}
The processing of residual waste production in the Karang Joang Water Treatment Plant with 100 LPS Capaty (Karang Joang WTP) is an effort of the City of Balikpapan PDAM to protect the environment from pollutants produced by Karang Joang WTP from the production process. The wastewater treatment conducted by the City of Balikpapan PDAM at the Karang Joang IPAM is useful to increase the volume of raw water through the process of reusing water produced by processing waste production. However, a precise calculation is needed given the limited land available.
\end{abstract}

Keywords-3-5 waste, water Treatment , Instalatiom, Karang Joang

\section{PENDAHULUAN}

Pengolahan limbah sisa produksi di instalasi pengolahan air minum Karang Joang (IPAM Karang Joang) merupakan upaya PDAM Kota Balikpapan untuk menjaga lingkungan dari bahan pencemar yang dihasilkan IPAM Karang Joang dari proses produksi. Pengolahan air limbah yang dilakukan PDAM Kota Balikpapan di IPAM Karang Joang bermanfaat untuk menambah volume air baku melalui proses pemanfaatan kembali air hasil pengolahan limbah produksi.

\section{METODE PENELITIAN}

\subsection{Metode yang lakukan adalah melakuakan}

1. survey lokasi serta wawancara

2. melakukan perhitungaan volume air limbah.

3. Pengukuran lama waktu endap dengan gelas ukur 
4. Menentukkan sistem Pengolahan berdasarkan ketersedian lahan dan volume limbah

\subsection{Perhitungan Dimensi Bak Pengendap Lumpur}

Bak pengendapan lumpur terbagi menjadi 2 aliran yaitu endapan lumpur yang mengalir ke bak pengering lumpur dan air yang digunakan kembali sebagai air baku IPAM Karang Joang.

\subsubsection{Pencucian filter}

Berlangsung selama 30 menit dengan debit aliran 0,12 m3/detik, intensitas kepekatan lumpur sedang berlangsung selama 10 menit dan 20 menit untuk tingkat kepekatan lumpur yang tinggi. Jenis pengendapan lumpur menggunakan jenis bak equalisasi

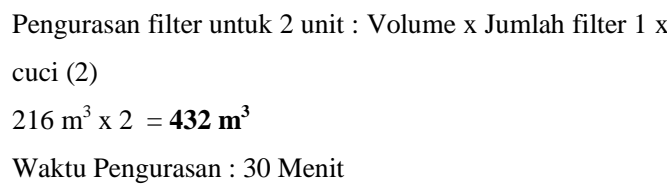

\subsubsection{Waktu Endap}

Sampel diambil $1000 \mathrm{ml}$ dengan waktu endap 15 menit jumlah endapan mencapai $400 \mathrm{ml}$ dan $600 \mathrm{ml}$ merupakan air yang siap digunakan kembali untuk air baku.

\subsection{Metode Pengolahan}
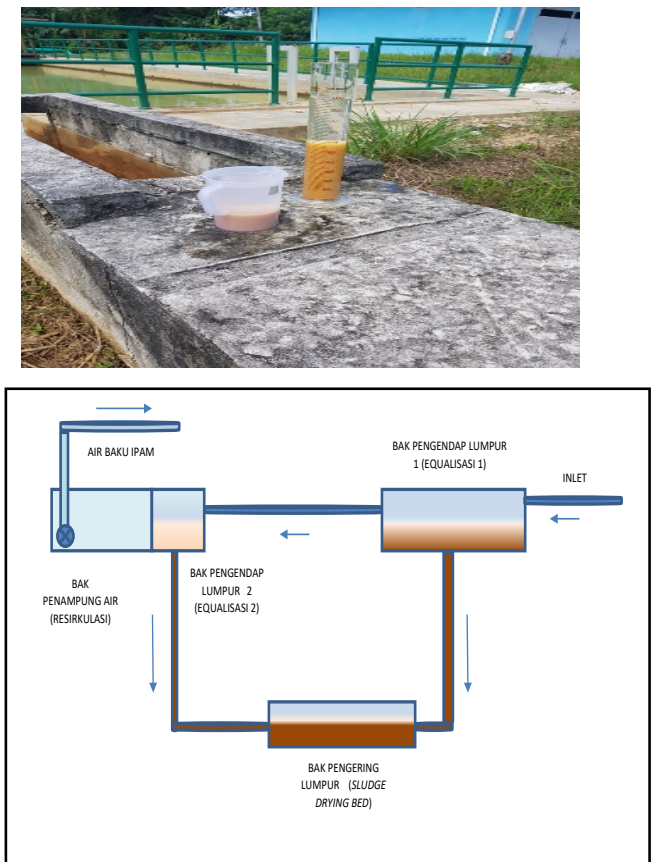

Metoda pengolahan yang dipilih dan di inginkan untukk pengolahan lumpur adalah konvensional yaitu Lagoon/Sludge Drying Bed (SDB) dikarenakan keterbatasan sumber daya listrik yang ada

\section{HASIL DAN PEMBAHASAN}

\subsection{Inlet}

Inlet berasal dari saluran terbuka yang terhubung dari IPAM Karang Joang ke lokasi pengolahan lumpur. Elevasi awal inlet adalah +16,25 mdpl dan elevasi ujung saluran buang +14 mdpl. Air limbah produksi dari IPAM Karang Joang disalurkan melalui pembuangan dengan saluran terbuka menuju ke unit pengolahan lumpur. Dimensi saluran terbuka lebar $40 \mathrm{~cm}$, tinggi $100 \mathrm{~cm}$ dan panjang 6600 $\mathrm{cm}$. Tinggi volume aliran maksimal yang melewati saluran terbuka adalah $40 \mathrm{~cm}$. Saluran pembuangan terbuka IPAM Karang Joang mampu menampung aliran fluida sebesar 240 liter/detik.

\subsection{Bak Penampung Air (Bak Resirkulasi)}

Sebagai tempat menampung air hasil pemisahan dengan lumpur sisa produksi di bak equalisasi. Air yang dapat digunakan sebagai air baku berjumlah $60 \%$ dari total air limbah sedangkan 40\% nya.

Volume air limbah $=432 \mathrm{~m} 3$

Volume Air Baku (60\%) = Volume air limbah $\mathrm{x}$ volume air baku $=432 \times 60 \%=259 \mathrm{~m} 3$ Volume Bak Resirkulasi $=$ Volume Air Baku Volume Bak Resirkulasi $=259 \mathrm{~m} 3$

\subsection{Bak Pengendap Lumpur (Bak Equalisasi)}

Sebagai bak pengendap mula dan memberikan waktu endap bereaksi, sehingga air dan lumpur dapat terpisah secara optimal. Bak pengendapan lumpur 2 memanfaatkan bangunan eksisting yang sebagian digunakan untuk bak resirkulasi, dengan penambahan sekat di antara 2 fungsi bak. Di bak equalisasi 2 ini kepekatan lumpur sudah berkurang drastis karena pengendapan optimal berlangsung di bak equalisasi 1 . 


\subsection{Bak Pengendap Lumpur 2}

Sebagai bak pengendap mula dan memberikan waktu endap bereaksi, sehingga air dan lumpur dapat terpisah secara optimal. Volume air limbah produksi IPAM Karang Joang yang diperhitungkan dengan 2 filter untuk satu kali cuci adalah sebesar $432 \mathrm{~m}^{3}$ dengan waktu buang selama 30 menit dan waktu endap selama 15 menit.

\section{KESIMPULAN}

a. Sistem pengolahan lumpur dengan sistem lagoon/SDB merupakan pilihan untuk limbah produksi IPAM Karang Joang, dikarenakan ketersediaan lahan dan keterbatasan sumber daya

b. Diperlukan pengukuran detail untuk nilai elevasi masing-masing bak pengolahan

\subsection{Bak Pengering Lumpur}

Berfungsi sebagai pengumpul lumpur ahir dari pengolahan limbah sisa produksi IPAM Karang Joang. Terdapat Lokasi dengan elevasi +10 mdpl yang layak untuk SDB

baik yang eksisting maupun rencana, sehingga sistem dapat bekerja optimal.

c. Detail desain unit pengendapan lumpur disesuaikan dengan kebutuhan kondisi debit inlet, sehingga lumpur dapat terendap sempurna.

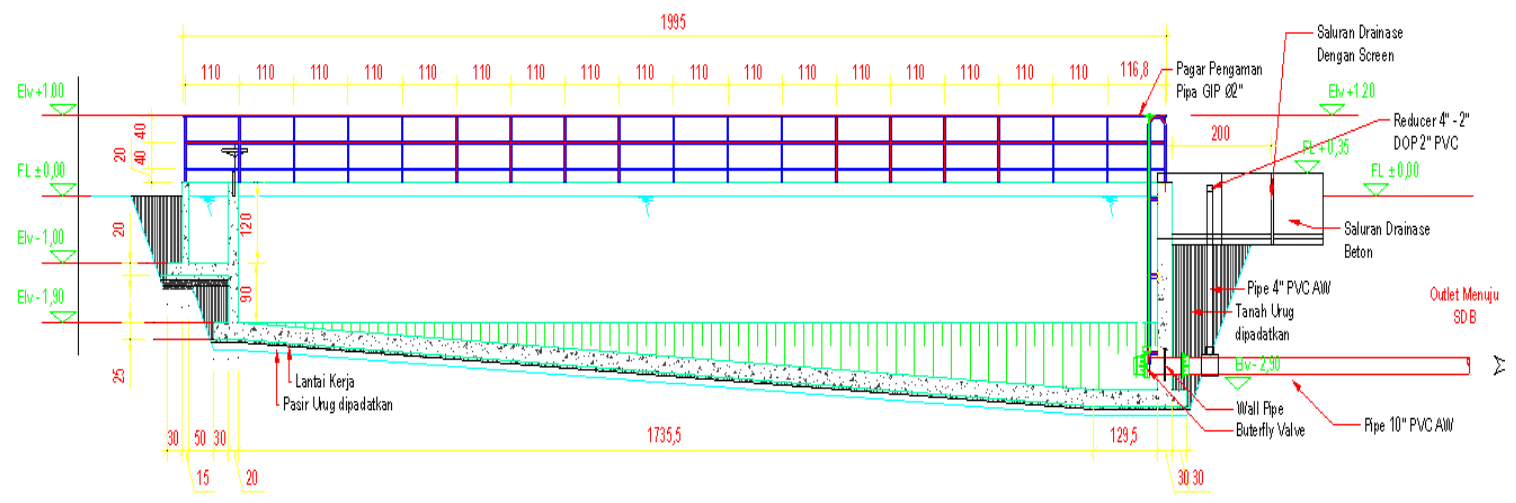

d. Bak pengendap lumpur dibuat bersekat dengan lantai dasar memiliki kemiringan, sehingga lumpur yang telah terkumpul menjadi flok dapat mengendap dengan cepat

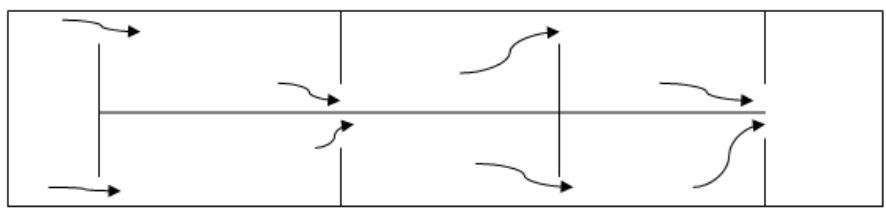

\section{UCAPAN TERIMA KASIH}

Penulis mengucapkan terima kasih kepada management dan bagian litbang PDAM Balikpapan yang telah memberi kesempatan untuk penelitian ini.

\section{DAFTAR PUSTAKA}

M. Gander, B. Jefferson, S. Judd. Aerobic MBRs for domestic wastewater treatment: A review with cost considerations. eparation and Purification Technology, 18 (2000) 119-130. 
J.J. Qin, M.H. Oo, G. Tao, K.A. Kekre. Feasibility study on petrochemical wastewater treatment and reuse using submerged MBR. Journal of membrane science, 293 (2007) 161166.

I.G. Wenten, A.N. Hakim, P.T.P. Aryanti. "Bioreaktor Membran untuk Pengolahan Limbah Industri.” Teknik Kimia Institut Teknologi Bandung, 2014.

I.G. Wenten, Khoiruddin, P.T.P. Aryanti, A.N. Hakim. "Pengantar Teknologi Membran.” Teknik Kimia Institut Teknologi Bandung, 2010.

I.G. Wenten, P.T.P. Aryanti, Khoiruddin. "Teknologi Membran dalam Pengolahan Limbah.” Teknik Kimia Institut Teknologi Bandung, 2014.

J.X. Ma, Z.W. Wang, Y. Yang. Correlating microbial community structure and composition with aeration intensity in submerged membrane bioreactor by 454 high throughout pyrosequencing. Water Res, 47 (2013) 859-69.

I. Jackvicz, A. Pierkiel, J. Lanting. Membrane coupled anaerobic digestion of sewarge sludge; a pilot study. Procedings of the water Environment Federation. WEF/A\&WMA Industrial Wastes. (2004) 144-50.

H. Wu, X. Huang. Improvement of membrane filterability of the mixed liquor in a membrane bioreactor by ozonation. J Membr Sci, 318 (2008) 210-216.

N.R. Khalili, E. Chaib, S.J. Parulekar, D. Nykiel. Performance enhancement of batch aerobic digesters via addition of digested sludge. J Hazard Mater, 76(1), (2000) 91-102.
R.C. Eusebio, H.G. Kim, T.H. Chung, H.S. Kim. Enhancing filterability of flat sheet membrane by addition of cationic polymer for sludge thickening system. Desalin water treat, 34 (2010) 10-8. 